\title{
Selecting Counties to Participate in Agricultural Carbon Compensation in China
}

\author{
Chuanhe Xiong ${ }^{1,2}$, Shuang Chen ${ }^{1 *}$, Degang Yang ${ }^{2}$ \\ 'Key Laboratory of Watershed Geographic Sciences, Nanjing Institute of Geography and Limnology, \\ Chinese Academy of Sciences, Nanjing, China \\ ${ }^{2}$ Xinjiang Institute of Ecology and Geography, Chinese Academy of Sciences, Urumqi, China
}

Received: 16 January 2018

Accepted: 28 February 2018

\begin{abstract}
Agriculture has the dual attributes of being a carbon source and a carbon sink. The agricultural carbon compensation mechanism is important for increasing agricultural carbon sink and reducing agricultural carbon emissions. However, there is no specific entry threshold for the implementation of agricultural carbon compensation in China. Taking the two indicators of agricultural carbon sink level and agricultural carbon emission intensity as the basic indicators, and taking the regional average agricultural carbon sink level and the regional average agricultural carbon emission intensity as the baseline, we established the agricultural carbon compensation area selection process. According to the agricultural carbon compensation area selection process, the results obtained in Hotan Prefecture were reasonable. The result of selection accorded with the actual situation of agricultural carbon emission and agricultural carbon sinks in Hotan Prefecture.
\end{abstract}

Keywords: agricultural carbon compensation mechanism, entry threshold, agricultural carbon sink level, agricultural carbon emission intensity, area selection process

\section{Introduction}

Climate change caused by greenhouse gas emissions has greatly affected the world. It has become the common goal of countries worldwide to address climate change, reduce GHG (greenhouse gases) emissions, and implement sustainable development strategies. China has proposed that by 2030 , its $\mathrm{CO}_{2}$ emissions per unit of GDP will have decreased by $60-65 \%$ compared with emissions in 2005.

In addition to the second and third industries, agriculture is also an important source of GHG emissions

*e-mail: schens@niglas.ac.cn
[1-3]. Approximately $17 \%$ of China's GHG emissions are from agriculture emissions [4], which is responsible for $>20 \%$ of global agricultural GHG [5]. Agricultural GHG emissions of $\mathrm{CH}_{4}$ and $\mathrm{N}_{2} \mathrm{O}$ account for $50 \%$ and $92 \%$ of China's total $\mathrm{CH}_{4}$ and $\mathrm{N}_{2} \mathrm{O}$ emissions, respectively [6].

Although agriculture is one of the main sources of anthropogenic greenhouse gases on earth, it also has a strong carbon sink function, which has great potential for greenhouse gas absorption. On the one hand, forests are the first recognized ones with carbon sinks. On the other hand, crops absorb much $\mathrm{CO}_{2}$ through photosynthesis, and the carbon content can reach $43-58 \%$ of total biomass [7]. Moreover, the potential of carbon sequestration in cultivated land is huge, 
the carbon sequestration of arable land in the world was $0.75-1.0 \mathrm{Pg} / \mathrm{a}$, and the world's carbon sequestration of farmland will be $20-30 \mathrm{Pg}$ in the next 50-100 years [7-9].

With the achievements in energy-related GHG emissions, renewables, and the plan to form a nationwide carbon-trading scheme, China can and will lead on climate change after the United States' exit from the 2015 Paris Agreement [10]. However, China does not do well in agricultural GHG emissions reduction [11]. Although China's agricultural GHG emissions intensity has declined [4], the total amount of agricultural GHG emissions still grew and had not yet reached the inflection point. A large amount of the rural labor force has flowed to the city [12], and the excessive dependence on agricultural machinery has increased. The development of agricultural S\&T (science and technology) level has been low and agriculture-related R\&D investment has been little. Farmers usually planted crops, raised livestock, and used the agrochemical inputs in an inefficient way just because they lacked knowledge and experience [2]. China lacked incentives, tax mechanisms, and compensation mechanisms on agricultural GHG emissions reduction [2]. 94\% of the world's countries had integrated agricultural GHG emissions into the GHG emission reduction system [13], and many countries had begun to implement relevant plans and policies to reduce agricultural GHG emissions, such as the United States, Japan, and India [14, 15]. As a large agricultural country, China should implement effective policies to reduce agricultural GHG emissions, and the agricultural carbon compensation mechanism especially needs to be established and improved, which is an effective mechanism to reduce agricultural GHG emissions [7, 16-21].

China's carbon compensation research focuses on the realization path of agricultural carbon sink values and researching the carbon trading market [7, 22-26]. In practice, agricultural carbon compensation has been mentioned in agricultural ecological compensation, such as grain subsidies, returning farmland to forests, returning farmland to grassland, and the construction of the three North Shelterbelt, etc., but only the subsidiary of the agricultural ecological compensation in the government compensation. In terms of market compensation, carbon market compensation develops slowly and focuses on forest resources. At present, most of the CDM projects in China are forest projects, and the domestic carbon trading pilot market is mainly aimed at forest carbon sinks in agriculture. In China, Sichuan and Shaanxi provinces and Xinjiang Uygur Autonomous Region have also carried out voluntary trading projects on agricultural greenhouse gas emissions reduction, such as formula fertilization by soil testing and drip irrigation [27]. However, these studies and projects have not given specific entry threshold for the implementation of agricultural carbon compensation. After fully understanding the basic situation of agricultural carbon compensation in China, we set up a simple threshold for participation in agricultural carbon compensation that can provide reference for regional participation in agricultural carbon compensation, at the same time making due the contribution to reduce agricultural GHG emissions.

\section{Material and Methods}

\section{Agricultural Carbon Emissions and Carbon Sink Calculations}

Agricultural carbon emissions are mainly considered to be the use of agricultural land, paddy fields, and livestock farming [4, 6, 28-30]. Carbon sinks mainly come from soil carbon sequestration of cultivated land throughout the life cycle of crop growth and carbon absorption in the economic forest [7, 31-33].

The formula for calculating agricultural carbon emissions is:

$$
E=\sum E_{i}=\sum T_{i} \mu_{i}
$$

...where $E$ is the total agricultural carbon emissions, $E_{i}$ is the agricultural carbon emissions of agricultural carbon source $i, T_{i}$ is the amount of agricultural carbon source $i$, and $\mu_{i}$ is the agricultural carbon emission coefficient of agricultural carbon source $i$. Three types of carbon emissions $\left(\mathrm{C}, \mathrm{CH}_{4}\right.$, and $\left.\mathrm{N}_{2} \mathrm{O}\right)$ have been calculated in this paper and we convert $\mathrm{CH}_{4}$ and $\mathrm{N}_{2} \mathrm{O}$ to standard carbon according to IPCC [34]. All of the carbon sources and coefficients in this paper are from the research of Xiong et al. [6].

The formula for calculating agricultural carbon sinks is:

$$
C=C S+C P+C F
$$

...where $C$ is total agricultural carbon sinks, $C S$ is the total soil carbon sequestration of cultivated land, $C P$ is the total carbon absorption in planting industry, and $C F$ is total carbon absorption in the economic forest. Concrete calculation methods of carbon sinks in this paper are from the research of Xiong et al. [7].

\section{Determining Entry Threshold Index}

In accordance with the existing studies about energy, GHG emissions, agricultural carbon emissions, and agricultural carbon sinks [2, 7, 35-44], we found that ACEI (agricultural carbon emission intensity) and ACSL (agricultural carbon sink level) were the core of these studies, so we determined that they were the threshold index.

$$
A C E I=\frac{E}{A G D P}
$$




$$
A C S L=\frac{C-E}{E}
$$

... where $A G D P$ is agricultural gross output value.

\section{Area Selection Process through Threshold Index}

The reason for the area selection through threshold index is that the current project is limited, the purpose is to make the project implementation obvious, the demonstration effect good, and farmers' incomes high. The area selection process through the threshold index is as follows (Fig. 1): the first step, choose the priority area to participate in agricultural net carbon sinks compensation through the comparison of ASCL (the ASCL values of the national, provincial, and prefecture level cities can be selected here); the second step, choose the priority area to participate in compensation of agricultural carbon sinks in low carbon mode through the comparison of ACEI (the ACEI values of the national, provincial, and prefecture level cities can be selected here), then make the determination of low carbon mode of agricultural carbon sinks compensation through analysis of agricultural carbon emissions structure in the selected area. The rest of the areas are waiting for opportunity.
Agricultural net carbon sinks compensation refers to the compensation for the net carbon sinks of agriculture, which belongs to the total factor carbon compensation, and the participating counties and cities were no longer involved in the compensation of agricultural carbon sinks in low carbon mode. Compensation of agricultural carbon sinks in low carbon mode refers to compensation for reduced agricultural carbon emissions in a low-carbon model. Reduction of agricultural chemicals, low carbon cultivation, and low carbon breeding refers to specific low carbon modes. "Waiting for opportunity" means that the areas that fail to be elected wait for other agricultural carbon compensation opportunities.

\section{Empirical Results: County Selection of Agricultural Carbon Compensation in Hotan Prefecture}

\section{Study Area}

Hotan Prefecture is located in the southernmost tip of the Xinjiang Uygur Autonomous Region. It covers an area of approximately $248,100 \mathrm{~km}^{2}$. Mountains in the prefecture account for $33.3 \%$, deserts account for $63 \%$, and the oasis accounts for $3.7 \%$. The oasis is divided

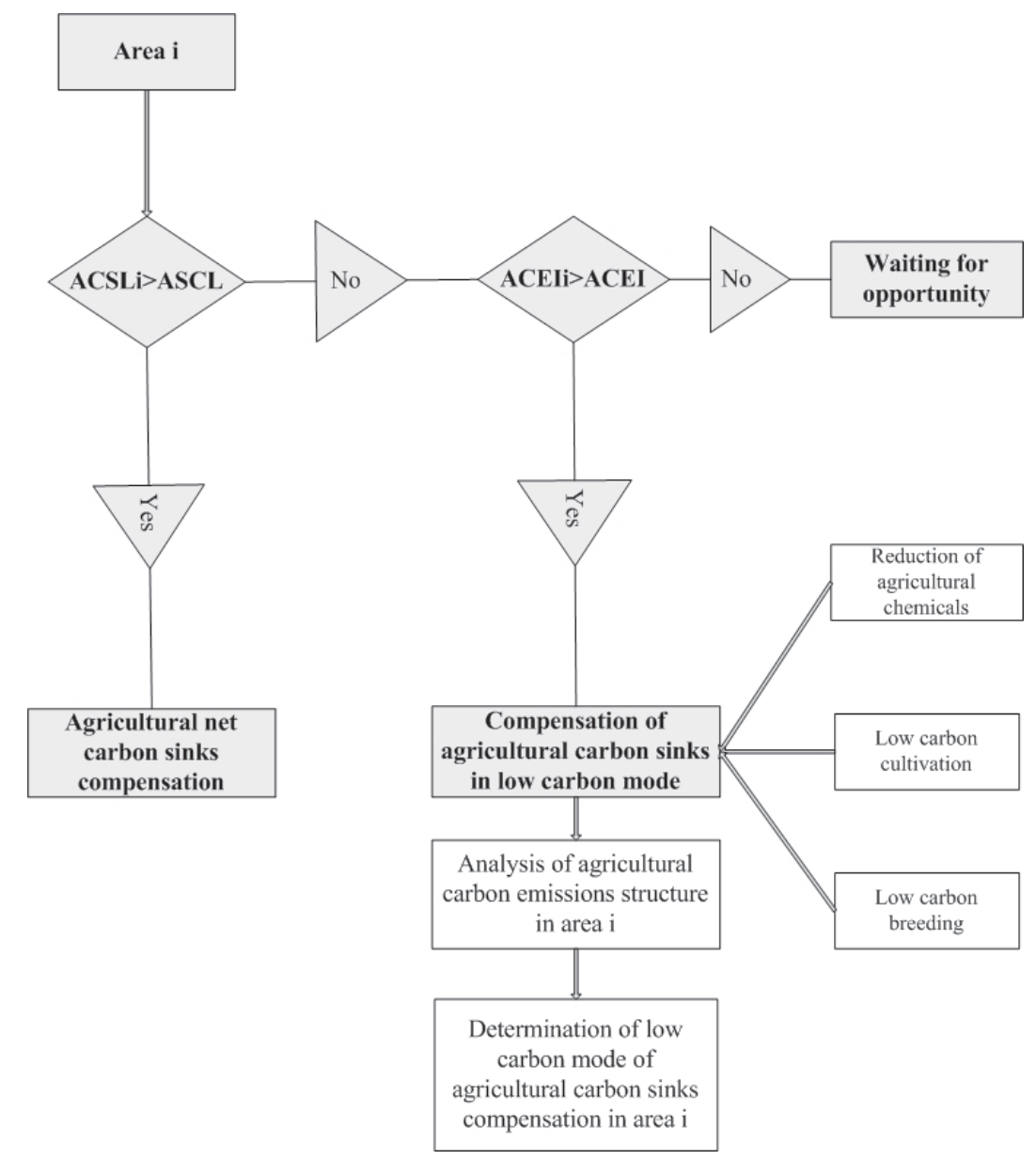

Fig. 1. Agricultural carbon compensation area selection process. 
Table 1. Agricultural carbon sinks of one city and 7 counties in Hotan Prefecture in 2014 (104 tons).

\begin{tabular}{|c|c|c|c|c|c|c|}
\hline Counties and cities & Commercial forest & Soil & $\begin{array}{c}\text { Planting } \\
\text { industry }\end{array}$ & $\begin{array}{c}\text { Total carbon } \\
\text { emissions }\end{array}$ & Net carbon sinks & Carbon sink level \\
\hline Hotan Prefecture & 195.70 & 237.56 & 155.61 & 78.10 & 510.76 & 6.54 \\
\hline Hotan City & 11.43 & 14.58 & 11.67 & 5.24 & 32.44 & 6.19 \\
\hline Hotan County & 35.42 & 33.40 & 19.24 & 12.34 & 75.72 & 6.14 \\
\hline Moyu County & 38.99 & 48.52 & 37.24 & 20.16 & 104.59 & 5.19 \\
\hline Pishan County & 27.66 & 39.92 & 21.54 & 8.44 & 80.68 & 9.56 \\
\hline Luopu County & 26.21 & 30.80 & 24.98 & 8.99 & 73.01 & 8.12 \\
\hline Cele County & 23.02 & 23.84 & 15.27 & 7.25 & 54.88 & 7.57 \\
\hline Yutian County & 26.31 & 42.33 & 23.19 & 11.90 & 79.93 & 6.72 \\
\hline Minfeng County & 6.65 & 4.16 & 2.49 & 3.87 & 9.43 & 2.44 \\
\hline
\end{tabular}

into more than 300 subsections by the desert and Gobi [6].

Hotan has a population of 2.15 million people, with 30 nationalities represented. Approximately $82.71 \%$ of the population works in agriculture. Its regional economy is dominated by agriculture, which can be divided into three main industries: planting, animal husbandry, and commercial forestry and fruit.

\section{Data Description}

Commercial forestry data are from the Bureau of forestry and other data in this study come from the Hotan Prefecture statistical yearbooks (2015).

\section{Empirical Results}

According to the agricultural carbon compensation area selection process (Fig. 1), Hotan's selection process is as follows:

(1) The agricultural carbon sink level in Hotan prefecture was selected as the standard, there were four counties (Pishan, Luopu, Cele, and Yutian) whose agricultural carbon sink levels were higher than that of Hotan Prefecture (Table 1). These counties were given priority to participate in the agricultural net carbon sink compensation project. Agricultural net carbon sink compensation belongs to the total factor carbon compensation, and the participating counties and cities were no longer involved in the compensation of agricultural carbon sinks in low-carbon mode.

(2) The agricultural carbon emission intensity in Hotan Prefecture was selected as the standard, and four counties (Minfeng, Moyu, and Hotan, plus Hotan City) whose agricultural carbon emission intensities were higher than that of the prefecture (Table 1). These counties were given priority to participate in compensation of agricultural carbon sinks in lowcarbon mode. Through the analysis of agricultural carbon emissions structure in Hotan Prefecture, we can see that carbon emissions from livestock breeding are dominant (Table 2). Therefore, these cities and counties gave priority to participation in low-carbon livestock breeding projects.

In this paper, the carbon emission intensity of the planting industry in Hotan Prefecture was chosen

Table 2. Agricultural carbon emissions of one city and 3 counties in Hotan Prefecture in 2014 ( $10^{4}$ tons).

\begin{tabular}{|c|c|c|c|c|c|c|c|c|c|c|}
\hline $\begin{array}{c}\text { Counties } \\
\text { and cities }\end{array}$ & $\begin{array}{c}\text { Carbon } \\
\text { emissions } \\
\text { from land } \\
\text { use }\end{array}$ & $\begin{array}{c}\text { Propor- } \\
\text { tion }\end{array}$ & $\begin{array}{c}\text { Carbon } \\
\text { emissions } \\
\text { from } \\
\text { paddy } \\
\text { field }\end{array}$ & $\begin{array}{c}\text { Propor- } \\
\text { tion }\end{array}$ & $\begin{array}{c}\text { Carbon } \\
\text { emissions } \\
\text { from } \\
\text { enteric } \\
\text { fermenta- } \\
\text { tion }\end{array}$ & $\begin{array}{c}\text { Propor- } \\
\text { tion }\end{array}$ & $\begin{array}{c}\text { Carbon } \\
\text { emissions } \\
\text { from } \\
\text { manure } \\
\text { emissions }\end{array}$ & $\begin{array}{c}\text { Propor- } \\
\text { tion }\end{array}$ & $\begin{array}{c}\text { Total } \\
\text { carbon } \\
\text { emis- } \\
\text { sions }\end{array}$ & $\begin{array}{c}\text { Carbon } \\
\text { emission } \\
\text { intensity } \\
\text { (kg/104AGDP) }\end{array}$ \\
\hline $\begin{array}{c}\text { Hotan Prefec- } \\
\text { ture }\end{array}$ & 24.66 & 0.3158 & 0.082 & 0.0010 & 26.36 & 0.3375 & 27.00 & 0.3457 & 78.10 & 1470.49 \\
\hline Hotan City & 1.89 & 0.3598 & 0.005 & 0.0009 & 1.65 & 0.3154 & 1.70 & 0.3239 & 5.24 & 1486.98 \\
\hline Hotan County & 3.42 & 0.2775 & 0.025 & 0.0020 & 4.55 & 0.3687 & 4.34 & 0.3518 & 12.34 & 1516.24 \\
\hline Moyu County & 5.33 & 0.2645 & 0.022 & 0.0011 & 7.64 & 0.3790 & 7.17 & 0.3554 & 20.16 & 1670.92 \\
\hline $\begin{array}{c}\text { Minfeng } \\
\text { County }\end{array}$ & 0.61 & 0.1564 & 0.000 & 0.0000 & 1.49 & 0.3836 & 1.78 & 0.4600 & 3.87 & 2873.51 \\
\hline
\end{tabular}




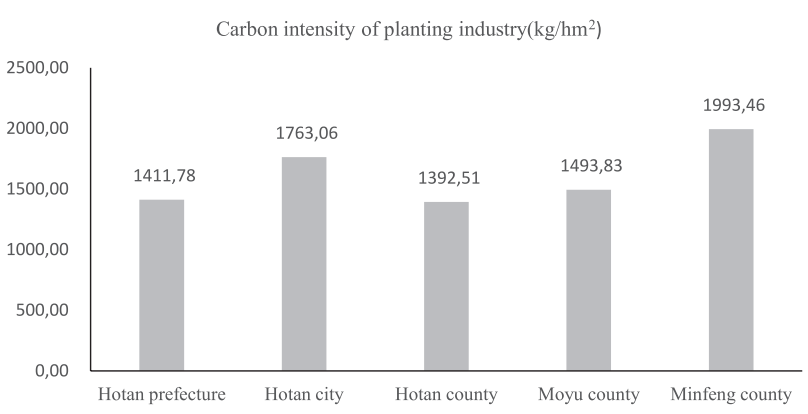

Fig. 2. Carbon intensity of planting industry of one city and 3 counties in Hotan Prefecture in 2014.

as the standard, and three entities (Minfeng County, Hotan City, and Moyu County) had agricultural carbon emission intensities of planting industry higher than that of Hotan Prefecture (Fig. 2). Through the analysis of carbon emission structure of the planting industry, carbon emissions mainly came from the use of chemical fertilizer (Table 3). Therefore, these counties and cities were given priority to participate in projects of the reduction of agricultural chemicals (reducing the use of chemical fertilizer).

\section{Discussion}

(1) According to the agricultural carbon compensation area selection process, the results obtained in Hotan Prefecture were reasonable. The result of selection was in accord with the actual situation of agricultural carbon emissions and agricultural carbon sink in Hetian Prefecture [6, 7].

(2) Because of the small scope in Hotan Prefecture, the index screening is relatively simple, and it will become complicated on the provincial and national scales.

(3) Agricultural greenhouse gas emissions without low carbon technologies are used as baseline, and carbon emission reductions in low-carbon models can be traded after certification by third-party certification bodies [27]. In this paper, the agricultural carbon sink mainly refers to the agricultural carbon reserves. The carbon sinks for trading mainly refer to the increase in carbon sinks due to the conversion of cultivated land into economic forests.
(4) The use of low-carbon technologies in any region can lead to the reduction of agricultural greenhouse gases, and any region can participate in agricultural carbon compensation. The reason for the area selection through threshold index is that the current project is limited, and the purpose is to make the project implementation obvious, have a good demonstration effect, and raise farmers' incomes. The ultimate goal is to reduce total agricultural greenhouse gas emissions.

(5) Entry threshold indexes and the agricultural carbon compensation area selection process are relatively simple. We need to increase judgment indicators so that the entry threshold is more systematic and scientific.

(6) Most of the studies on agricultural carbon emissions and agricultural carbon sinks are based on the unified coefficient $[4,6,28-30]$. Needless to say, this is not reasonable, because there is a big gap in agricultural greenhouse gas emission coefficients between different regions on a large scale, and so is the calculation of agricultural carbon sinks. Agricultural carbon compensation requires more scientific statistical coefficients.

\section{Conclusions}

Agriculture is an important carbon source, with $94 \%$ of the world's countries having integrated agricultural GHG emissions into the GHG emissions reduction system after the Paris Climate Conference [13]. At the same time, it also has a strong carbon sink function. Agricultural carbon compensation mechanism is an important mechanism for increasing agricultural carbon sink and reducing agricultural carbon emissions. However, there is no specific access threshold for implementating agricultural carbon compensation. We set up a simple threshold for participation in agricultural carbon compensation that can provide a reference for regional participation in agricultural carbon compensation.

Taking the two indicators of agricultural carbon sink level and agricultural carbon emission intensity as the basic indicators, and taking the regional average agricultural carbon sink level and the regional average agricultural carbon emission intensity as the baseline, we established the agricultural carbon compensation area selection process. According to the agricultural carbon compensation area selection process, the results

Table 3. Carbon emissions from planting industry in one city and 3 counties in 2014 (tons).

\begin{tabular}{|c|c|c|c|c|c|c|c|c|}
\hline $\begin{array}{c}\text { Counties } \\
\text { and cities }\end{array}$ & $\begin{array}{c}\text { Chemical } \\
\text { fertilizer }\end{array}$ & Pesticides & $\begin{array}{c}\text { Plastic } \\
\text { sheeting }\end{array}$ & Diesel & $\begin{array}{c}\text { Cultivated } \\
\text { land }\end{array}$ & Irrigation & $\begin{array}{c}\text { Paddy } \\
\text { field }\end{array}$ & $\begin{array}{c}\text { Total carbon emissions } \\
\text { from planting industry }\end{array}$ \\
\hline Hotan Prefecture & 158977.06 & 2188.60 & 21854.42 & 17920.28 & 548.67 & 45138.37 & 817.32 & 247444.73 \\
\hline Hotan City & 12239.27 & 45.66 & 1647.24 & 2121.27 & 34.34 & 2764.61 & 47.25 & 18852.39 \\
\hline Moyu County & 37318.76 & 507.11 & 3890.18 & 2021.11 & 112.23 & 9471.71 & 224.00 & 53321.09 \\
\hline Minfeng County & 4462.77 & 60.74 & 264.18 & 382.88 & 10.04 & 880.66 & 0.00 & 6061.28 \\
\hline
\end{tabular}


obtained in Hotan Prefecture were reasonable. The result of selection accorded with the actual situation of agricultural carbon emission and agricultural carbon sink in Hotan Prefecture [6, 7].

Due to the limitations of the author's research, entry threshold indexes and the agricultural carbon compensation area selection process need to be improved and expanded upon, such as agricultural carbon compensation scale, scientific statistical coefficients, and so on. These research topics call for the author to make further studies in the future.

\section{Acknowledgements}

This work was supported by Jiangsu Natural Science Foundation (BK20181105), the autonomous deployment project of Nanjing Institute of Geography and Limnology, CAS (NIGLAS2017QD12) and the Strategic Priority Research Program A of the Chinese Academy of Sciences (XDA20010301).

\section{Conflict of Interest}

The authors declare no conflict of interest.

\section{References}

1. DACE E., MUIZNIECE I., BLUMBERGA A., KACZALA A. Searching for solutions to mitigate greenhouse gas emissions by agricultural policy decisions Application of system dynamics modeling for the case of Latvia. Science of the Total Environment. 527-528, 80, 2015.

2. XIONG C.H., YANG D.G., XIA F.Q., HUO J.W. Changes in agricultural carbon emissions and factors that influence agricultural carbon emissions based on diferent stages in Xinjiang, China. Sci. Rep. 6, 36912, 2016.

3. STEVANOVIC M., POPP A., BODIRSKY B.L. Mitigation Strategies for Greenhouse Gas Emissions from Agriculture and Land-Use Change: Consequences for Food Prices. Environ. Sci. Technol. 51, 365, 2017.

4. TIAN Y.,ZHANG JB, HE Y.Y. Research on SpatialTemporal Characteristics and Driving Factor of Agricultural Carbon Emissions in China. Journal of Integrative Agriculture. 13(6), 1393, 2014.

5. NORSE D. Low carbon agriculture: objectives and policy pathways. Environment Development. 59, 25, 2012.

6. XIONG C.H., YANG D.G., HUO J.W. Spatialtemporal characteristics and LMDI-based impact factor decomposition of agricultural carbon emissions in Hotan Prefecture, China. Sustainability. 8 (3), 262, 2016.

7. XIONG C.H., YANG D.G., HUO J.W., ZHAO Y.N. Agricultural Net Carbon Effect and Agricultural Carbon Sink Compensation Mechanism in Hotan Prefecture, China. Polish Journal of Environmental Studies. 26 (1), 365, 2017

8. COLE C.V. Agricultural Options for Mitigation of Greenhouse Gas Emission (C) .Watson R. T., Znyowera M. C., Moss R. H. Climate Change 1995 - Impacts Adaptions and Mitigation of Climate Change Intergovernmental Panel on Climate Change. Cambridge: Cambridge University Press, 1, 1996.

9. LAL R., KimBle J. M., FOLLETT R. F., COLE C. V. The Potential of US Cropland to Sequester Carbon and Mitigate the Greenhouse Effect. Chelsea MI: Sleeping Bear Press, 128, 1998.

10. WANG C., WANG F. China can lead on climate change. Science. 357, 764, 2017

11. XIONG C.H., CHEN S., YANG D.G. China should reduce agricultural greenhouse gas emissions to enhance its ability to lead on global climate change. Science. 2017. (E-letter, 5 October 2017) http://science.sciencemag.org/ content $/ 357 / 6353 / 764.1 /$ tab-e-letters.

12. LIU Y., LI Y. Revitalize the world's countryside. Nature. 548, 275-277, 2017

13. FAO. The state of food and agriculture. FAO: Rome, Italy, $15,2016$.

14. GAO S., HUANG X., ZHAO R. Low carbon development model and policy research in Jiangsu, Nanjing University Press, 2013 [In Chinese].

15. GEWIN V., MONAHAN P. Us moves cut greenhouse emissions farms new study finds big global challenge. Science, 2016. http://www.sciencemag.org/news/2016/05/ us-moves-cut-greenhouse-emissions-farms-new-studyfinds-big-global-challenge.

16. SILVER J. The potentials of carbon markets for infrastructure investment in sub-Saharan urban Africa. Current Opinion in Environmental Sustainability. 13, 25, 2015.

17. KRAGT M.E., GIBSON F.L., MASEYK F., WILSON K.A. Public willingness to pay for carbon farming and its co-benefits. Ecological Economics. 126, 125, 2016.

18. LEE J., INGALLS M., ERICKSON J.D., WOLLENBERG E. Bridging organizations in agricultural carbon markets and poverty alleviation: An analysis of pro-Poor carbon market projects in East Africa. Global Environmental Change. 39, 98, 2016.

19. CRETI A., JOETS M. Multiple bubbles in the European Union Emission Trading Scheme. Energy Policy. 107, 119, 2017.

20. LI W., JIA Z. J. Carbon tax, emission trading, or the mixed policy: which is the most effective strategy for climate change mitigation in China? Mitig Adapt Strateg Glob Change. 22, 973, 2017

21. LI X. Y., TANG B. J. Incorporating the transport sector into carbon emission trading scheme: an overview and outlook. Nat Hazards. 88, 683, 2017.

22. XIA Q L. Research on Agricultural Carbon Sinks in China [EB/OL]. 2010. http : //www .docin .com/ p -56175329 . html. [In Chinese].

23. XIE G.D., LI S.M., XIAO Y., QI Y. Value of carbon sink concept and evaluation. Journal of nature resource. 26 (1), 1, 2011 [In Chinese].

24. TAN X.P., WANG X.Y. The market performance of carbon trading in China: A theoretical framework of structureconduct-performance. Journal of Cleaner Production. 159, 410, 2017.

25. ZHAO X.G., WU L., LI A. Research on the efficiency of carbon trading market in China. Renewable and Sustainable Energy Reviews. 79, 1, 2017.

26. SONG Y.Z., LIU T.S., LI X., Liang D.P. Region division of China's carbon market based on the provincial/ municipal carbon intensity. Journal of Cleaner Production. 164, 1312, 2017. 
27. 2SUN F. Agricultural greenhouse gas emission reduction market mechanism in China: a case study of agricultural voluntary emission reduction project in Xinjiang, Sichuan. Beijing, Chinese Academy of Agricultural Sciences, 2011 [In Chinese].

28. JOHNSON JANE M.F. Agricultural opportunities to mitigate greenhouse gas emissions. Environmental Pollution. 150, 107, 2007.

29. HERRERO M., HENDERSON B., HAVLIK P. Greenhouse gas mitigation potentials in the livestock sector. Nature Climate Change. 6, 452, 2016.

30. YUE Q., XU X., HILliER J., CHENG K., PAN G. Mitigating greenhouse gas emissions in agriculture: From farm production to food consumption. Journal of Cleaner Production. 149, 1011, 2017.

31. FANG J.Y., GUO Z.D., PIAO S.L., CHEN A.P. Estimation of terrestrial vegetation carbon sinks in China from 1981 to 2000. Science in China (Series D: Earth Sciences). 37 (6), 804, 2007 [In Chinese].

32. ZHANG D. D., ZHANG S. M., HUANG W. Estimation of carbon sources and sinks of the agricultural system in Zhejiang Province. Chinese Journal of Agricultural Resources and Regional Planning. 33 (5), 12, 2012 [In Chinese].

33. LIU K., JIANG S.H., ZHU W.Y. Estimation of carbon sequestration value and analysis of space effect of forests in Guangdong Province. Chinese Journal of Agricultural Resources and Regional Planning. 36 (3), 120, 2015 [In Chinese].

34. IPCC. Climate Change 2014: Synthesis Report. Contribution of Working Groups I, II and III to the Fifth Assessment Report of the Intergovernmental Panel on Climate Change [Core Writing Team, R.K. Pachauri and L.A. Meyer (eds.)]. IPCC, Geneva, Switzerland, 151, 2014.

35. TAN Z., LI L., WANG J., WANG J. Examining the driving forces for improving China's $\mathrm{CO}_{2}$ emission intensity using the decomposing method. Applied Energy. 88, 4496, 2011.
36. LIU Y., ZHOU Z., ZHANG X. Net global warming potential and greenhouse gas intensity from the double rice system with integrated soil-crop system management: A three-year field study. Atmospheric Environment. 116, 92, 2015.

37. PRATIBHA G., SRINIVAS I., RAO K.V. Net global warming potential and greenhouse gas intensity of conventional and conservation agriculture system in rainfed semiarid tropics of India. Atmospheric Environment. 145, 239, 2016.

38. WANG Z., ZHANG B., LIU T. Empirical analysis on the factors influencing national and regional carbon intensity in China. Renewable and Sustainable Energy Reviews. 55, 34, 2016.

39. ZHANG W., LI K., ZHOU D., ZHANG W., GAO H. Decomposition of intensity of energy-related $\mathrm{CO}_{2}$ emission in Chinese provinces using the LMDI method. Energy Policy. 92, 369, 2016.

40. CARLSON K.M., GERBER J.S., MUELLER N.D. Greenhouse gas emissions intensity of global croplands. Nature Climate Change. 7, 63, 2017.

41. LI W., SUN W., LI G.M., CUI P.F., WU W., JIN B.H. Temporal and spatial heterogeneity of carbon intensity in China's construction industry. Resources, Conservation \& Recycling. 126,162, 2017.

42. WANG C., WEN B., WANG F., JIN L., YE Y. Factors Driving Energy-Related Carbon Emissions in Xinjiang: Applying the Extended STIRPAT Model. Polish Journal of Environmental Studies, 26, 1747, 2017.

43. ZHANG X., ZHAO Y., SUN Q., WANG C. Decomposition and Attribution Analysis of Industrial Carbon Intensity Changes in Xinjiang, China. Sustainability, 9, 459, 2017.

44. WANG C., WANG F., ZHANG X., YANG Y., SU Y., YE Y., ZHANG H. Examining the driving factors of energy related carbon emissions using the extended STIRPAT model based on IPAT identity in Xinjiang. Renewable and Sustainable Energy Reviews, 67, 51, 2017. 
